\title{
DNA Splicing by Directed Ligation (SDL)
}

\author{
Yuri A. Berlin \\ Shemyakin-Ovchinnikov Institute of Bioorganic Chemistry, Russian Academy of \\ Sciences, Moscow 117871, Russia
}

\begin{abstract}
Splicing by directed ligation (SDL) is a method of in-phase joining of PCR-generated DNA fragments that is based on a pre-designed combination of class IIS restriction endonuclease recognition and cleavage sites. Since these enzymes cleave outside of their recognition sites, the resulting sticky end can have any desired sequence, and the site itself can be removed and does not appear in the final spliced DNA product. SDL is based on the addition of class IIS recognition sites onto primers used to amplify DNA sequences. Cleavage of the PCR products results in elimination of the recognition site-containing flanking sequences and leaves the DNA fragments crowned with protruding ends. With careful design of the sticky ends, several segments can be ligated together in a predetermined order in a single reaction. SDL requires fewer rounds of amplification than overlap extension methods, and is particularly useful for creating a series of recombinants that differ in one segment.
\end{abstract}

\section{Introduction}

The essence of genetic engineering lies in the purposeful shuffling of DNA fragments. These fragments may be obtained by synthesis or degradation in vivo (biologically), in vitro (biochemically), or in retorta (chemically). In the sixties, at the outset of genetic engineering, in vitro recombination of DNA sequences was based on the chemical synthesis of DNA duplexes (at an average rate of a monomer per month) with predesigned cohesive ends, which provided the structural basis for subsequent ligation (reviewed in 1). Interestingly, Khorana developed this strategy and went rather far along these lines even before the key enzyme, T4 DNA ligase, first called polynucleotide ligase, was discovered. The alternative approach at that time used terminal deoxynucleotidyl transferase-mediated DNA tailing (2, reviewed in 3).

The advent of restriction endonucleases (RE) in the early seventies radically changed the situation by allowing long DNA molecules to be cut into defined fragments (reviewed in 4,5). This proved to be a powerful complement to molecular cloning and in vivo amplification. Joining DNA fragments by ligation at restriction sites became ubiquitous. Applications of oligonucleotide synthesis, which still remained a highly sophisticated art, narrowed. Its main functions were reduced to obtaining fragments which did not exist in nature, or which could not be excised from DNA because suitable restriction sites were unavailable, or to supplying synthetic restriction sites.

This situation changed crucially when PCR was developed in the late eighties $(6,7)$. Virtual excision of any fragment of any DNA and its amplification (this time 
in vitro) became possible, provided some structural information necessary for designing the PCR primers was available. Dependence on chemical or chemical-enzymatic polynucleotide synthesis and restriction sites almost disappeared. Paradoxically, by that time the technology of oligonucleotide synthesis had attained a level of which "no mortal ever dared to dream before" - the average rate of chain extension reached a monomer per minute (reviewed in 8).

Although many sequences of earlier unthought-of lengths have been synthesized during the last ten years, synthesis has been used mainly to meet the formidable and still growing demand for relatively short primers. However, the problem of joining together DNA fragments of any origin - including PCR products - in a predetermined fashion remained topical. It was largely solved by the elegant method of gene splicing by overlap extension (SOE) (9-11). In the course of a search for other approaches, the DNA splicing by directed ligation (SDL) method was proposed (Figure 1; 12$15)$.

\section{Class IIS Restriction Endonucleases as Tools in SDL}

The problem of the in-phase combining of DNA fragments can be handled by supplying each pair of PCR products to be joined with cohesive (complementary protruding) ends, followed by ligation. If each pair of the ends is structurally specific, a mixture of fragments can be directed to ligate together in a predetermined order and orientation.

To generate structurally specific protruding ends in PCR products, class IIS restriction endonucleases (REIIS) can be used. These enzymes, similar to the standard REII, recognize specific sequences in double-stranded DNA. In contrast to class II restriction enzymes, however, class IIS enzymes cleave DNA at some distance outside, rather than inside, their recognition site (for review see 16). Thus, the recognition and cleavage sites in DNA are separate for these enzymes (see Table 1). In a non-PCR context REIIS recognition sites were used in synthetic adapters or special cloning vectors for the preparation of DNA fragments with predesigned protruding ends and their ligation (17-23).

The sequences required for each cohesive end may be included in the "pendant end" of the amplification primer, that is, the 5'-part, where non-complementarity to the template does not compromise PCR (24). Sequences in the pendant end of a PCR primer become incorporated into the product after the first two rounds of amplification.

Most REIIS make two cuts in the double-stranded DNA, though a few cleave four phosphodiester bonds to excise the recognition site. The two strands are almost always cut at different distances from the recognition site, so that a protruding end is generated [AccBSI (BstBI) CCGCTC(3/3) is an exception]. As REIIS-recognition sites are not symmetrical (nonpalindromic), the DNA cleavage is anisotropic: the positions of the cuts, and therefore of the protruding end, depend upon the orientation of the recognition site. The sequence of the overhanging end is independent of the recognition site and is only defined by the sequence of the cleavage site. This makes REIIS-generated protruding ends structurally specific, in contrast to the self-complementary sticky ends resulting from cleavage within palindromic REII-sites. Directed ligation thus imposes no limits on the product sequence.

\section{REIIS-generated Protruding Ends}

Among those REIIS that cut DNA unilaterally with regard to the recognition site, only $\mathrm{HgaI}$ (GACGC 5/10) gives as long as pentanucleotide protruding ends. A series of enzymes yields tetranucleotide ends. Formidable experience with REII-based DNA manipulations has shown that four-base overhangs are adequate for efficient ligation.

The efficacy of ligation does not seem to be affected by which end (5'- or 3'-) is 
DNA Splicing by Directed ligation 23
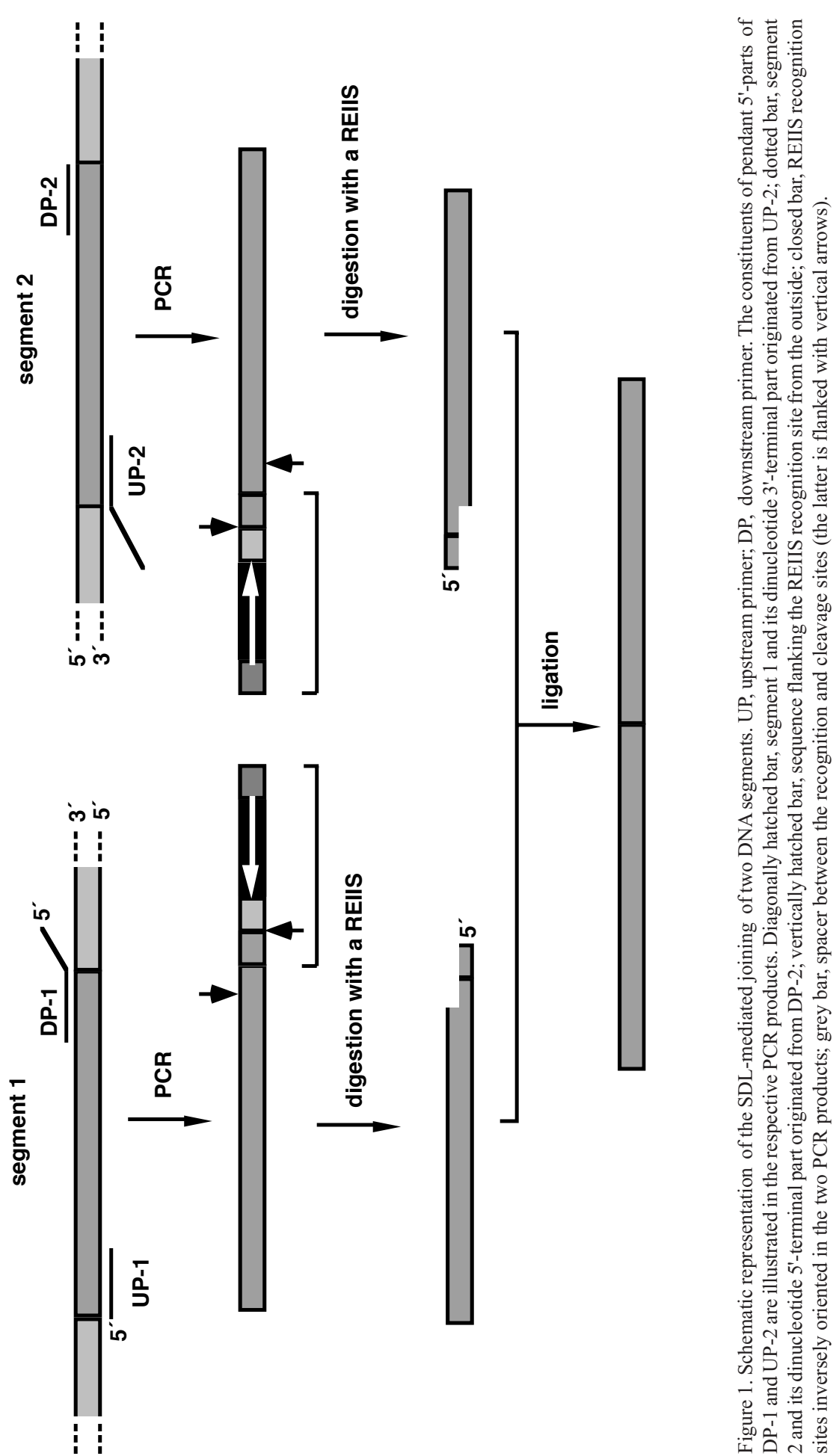
Table 1. Class IIS restriction endonucleases

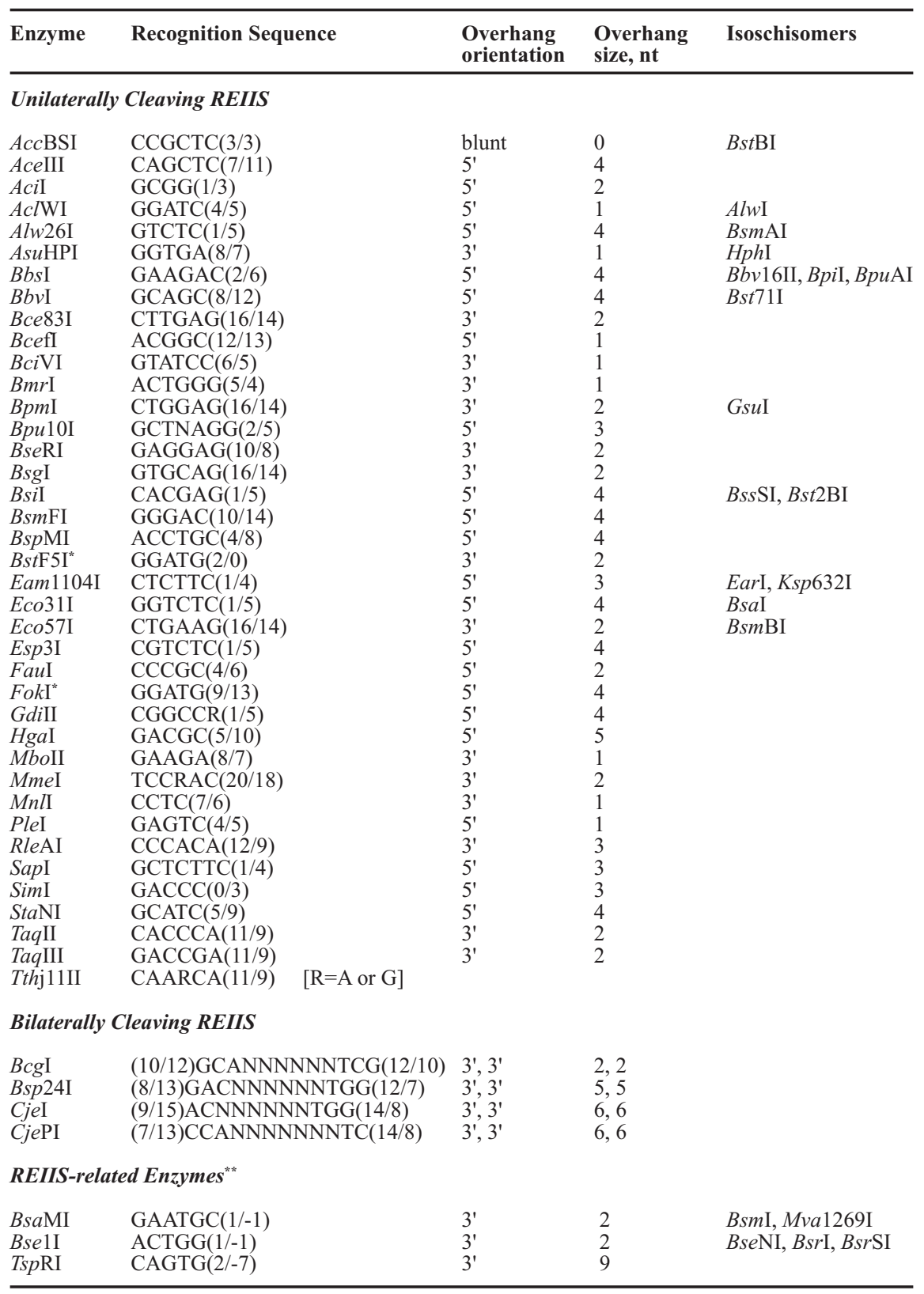

* BstF5I and FokI have the same recognition site but different cleavage sites (false isoschisomers).

**The recognition and cleavage sites of these three endonucleases are not completely separated. This is 
protruding. Nevertheless, 5'-protrusion, which occurs more frequently, has a certain appeal, because it allows labeling the DNA duplex by filling the 3'-recession with dNTPs and DNA polymerase. Also, 5'-terminal phosphorylation is easier to perform with the 5'-protrusion. This appeal, however, can be offset by a potential complication. It turns out that Taq DNA polymerase may well survive the standard stages of DNA deproteinization, and the same is true about $\operatorname{dNTPs}(25,26)$; even gel-electrophoretic purification of PCR product may fail to remove the polymerase bound to the DNA (27). Hence, if the isolated PCR product is to be directly digested with a REIIS (i.e. without intermediate blunt-end cloning), residual polymerase and triphosphates would fill in the 5'-overhang and thus entirely distort the strategy based on these protrusions. Though deproteinization $(25,26)$ could help the situation when using a 5 '-overhang, it may be wise to use 3'-protrusions that cannot be filled in.

The length of the protruding end has to do not only with the stability of association, whose formation precedes, or at least is concerted with, ligation, but also with the diversity of the overhang sequences, which provides specificity in a multicomponent joining. In fact, even with dinucleotide protruding ends, the total number of possible end variants $\left(2^{4}\right.$, i.e. 16) looks sufficient, while in the case of tetranucleotide ends the respective value $\left(4^{4}\right.$, i.e. 256$)$ far exceeds any plausible number of DNA segments to be joined in one reaction mixture. In principle, this makes it practical to use a one-pot ligation of any set of segments to yield the target sequence.

\section{Size of Recognition Site}

Besides the length of cohesive ends, there is a matter of the length of the recognition site. In fact, the choice is limited: there is only one enzyme with 7-bp (SapI, GCTCTTC 1/4) and one with 4-bp (MnlI, CCTC 7/6), whereas all other enzymes have 5- or 6-bp recognition sites. Naturally, a longer site implies less frequent random occurrence and thus simplifies manipulations of DNA, so the first choice apparently lies with a hexanucleotide site.

\section{Structural Elements of PCR Primers for SDL}

Each PCR primer for SDL should contain, along with the 3'-region perfectly matching the template, a pendant 5'-segment. This pendant segment comprises an REIIS cleavage site (where the protruding end will be generated after cutting) and, closer to the 5'-terminus, the recognition site for the endonuclease. The distance between the two sites is defined by the particular enzyme chosen; it may vary between 0 (BsrDI) and $20 \mathrm{nt}(\mathrm{MmeI})$. In a pair of amplification primers for a given segment, the two recognition sites should be in opposite orientations, so that both nucleolytic double-stranded cleavages of the PCR product are directed into the duplex. This organization results in the elimination of the two flanking recognition sites and leaves the coding sequence crowned with two protruding ends for the subsequent joining.

To generate a pair of complementary protruding ends in two DNA fragments to be joined, the corresponding primers (downstream primer for one DNA segment and upstream primer for the other) should contain identical stretches, which upon amplification yield two identical double-stranded REIIS cleavage sites. The two sites, after RE-digestion and ligation, merge to give a contiguous DNA segment.

It is recommended that the 5 -ends of the primers be designed to contain one to three nucleotide units, preferentially $\mathrm{G}$ or $\mathrm{C}$, to clamp the ends and hinder breathing. If an intermediate blunt-end cloning of the PCR products is going to be undertaken, the clamp would make up for possible short deletions at the joining sites, which may affect the 5'-terminus of the primer and therefore the REIIS-recognition site. If the PCR product is to be directly digested with a REIIS, the clamp may prevent a decrease in the enzyme's activity, which occurs if the restriction site is not flanked (28-30; Lebedenko and Berlin, unpublished). 
Synthesis and Cloning of Genes by Means of SDL

This strategy was employed $(13,14)$ for the REIIS Eco31I (GGTCTC 1/5)-mediated synthesis of an intronless gene encoding mature human interleukin $1 \alpha$ (IL1 $\alpha)$, a cytokine possessing a wide spectrum of biological activity (for review see 31). The functionally active 159-mer polypeptide is the C-terminal part of a 271-mer precursor (amino acids 113 to 271). It is encoded by three genomic segments: the end of exon 5 , all of exon 6, and the first part of exon 7. This simple structure seemed to beg to be an object in a model gene synthesis. The genomic structure of the IL1 $\alpha$ gene had been elucidated (32), which made the design of the primers for the SDL synthesis straightforward.

Among six primers needed for amplification of the three exon fragments, each of the four internal primers bore, in its pendant 5'-terminal region, an Eco31I recognition site in the same orientation, viz. its GGTCTC-strand. In each PCR product this provided the opposite ("tail-to-tail") orientation of the two flanking recognition sites. The two external primers introduced the translation initiation codon and an additional termination codon into the final spliced sequence, as well as BamHI restriction sites for inserting this sequence into a cloning vector.

Each internal primer also contained, at a distance of one nucleotide pair downstream of the restriction site, a tetranucleotide sequence coinciding with the prospective cohesive end. This sequence is the precursor of a double-stranded Eco31I cleavage site to be formed after PCR, which, in turn, gives rise to the cohesive end after the endonuclease digestion. In any pair of PCR product termini to be joined, these cleavage sites were designed to generate complementary protruding ends. Each of the ends contained two 5'-terminal nucleotides of its own segment (from the complementary part of the primer) and two 3'-terminal nucleotides of the second segment to be joined (from the pendant part of the same primer). Note that the joining site need not be located symmetrically relative to the boundaries of the two segments, although such disposition looks optimal. The approach can be seen by comparing Figures 1 and 2.

Three exon fragments were PCR amplified from human genomic DNA. Because the three amplifications were highly specific, it would have been possible to directly follow with the endonuclease cleavage and ligation. However, since they were of interest in studying functional topography of the protein molecule, each of the exons was first cloned individually. To assemble the gene, the plasmid DNAs containing the three exon fragments were digested with Eco31I and, when necessary, BamHI. The four exon fragments (exon 7 gave an additional fragment because of the presence of an endogenous $E c o 31$ I site) were ligated in a single reaction. The resulting mixture was treated with $B a m \mathrm{HI}$ endonuclease to cleave concatenated products, and the monomeric gene sequence was isolated by PAGE and cloned into an expression vector (14).

An efficient synthesis of a gene coding for isozyme $\mathrm{c}$ of horseradish peroxidase was carried out by means of a similar approach using another REIIS (FokI; GGATG 9/13) and chemical-enzymatic preparation of the gene's fragments. Forty oligonucleotides were chemically synthesized, divided into three groups, and ligated. These multicomponent ligation mixtures served as templates for three separate PCRs with pairs of primers provided with the FokI recognition sites and suitable cleavage sites. The PCR products were ligated sequentially or simultaneously to give the target gene (15).

In studying prokaryotic expression of some artificial eukaryotic genes (IL-1 $\alpha$ and IL-1 receptor antagonist), the SDL method was used for constructing an efficient two-cistron expression system with the termination codon of the first cistron and initiation codon of the second cistron partially overlapping $(33,34$; see Figure 2). This system is based on the vector pGMCE, a derivative of pGEM1 containing a chemically synthesized minicistron under control of the T7 promoter and the T7 gene 10 translation enhancer. These regulatory sequences are succeeded by an Eco31I 


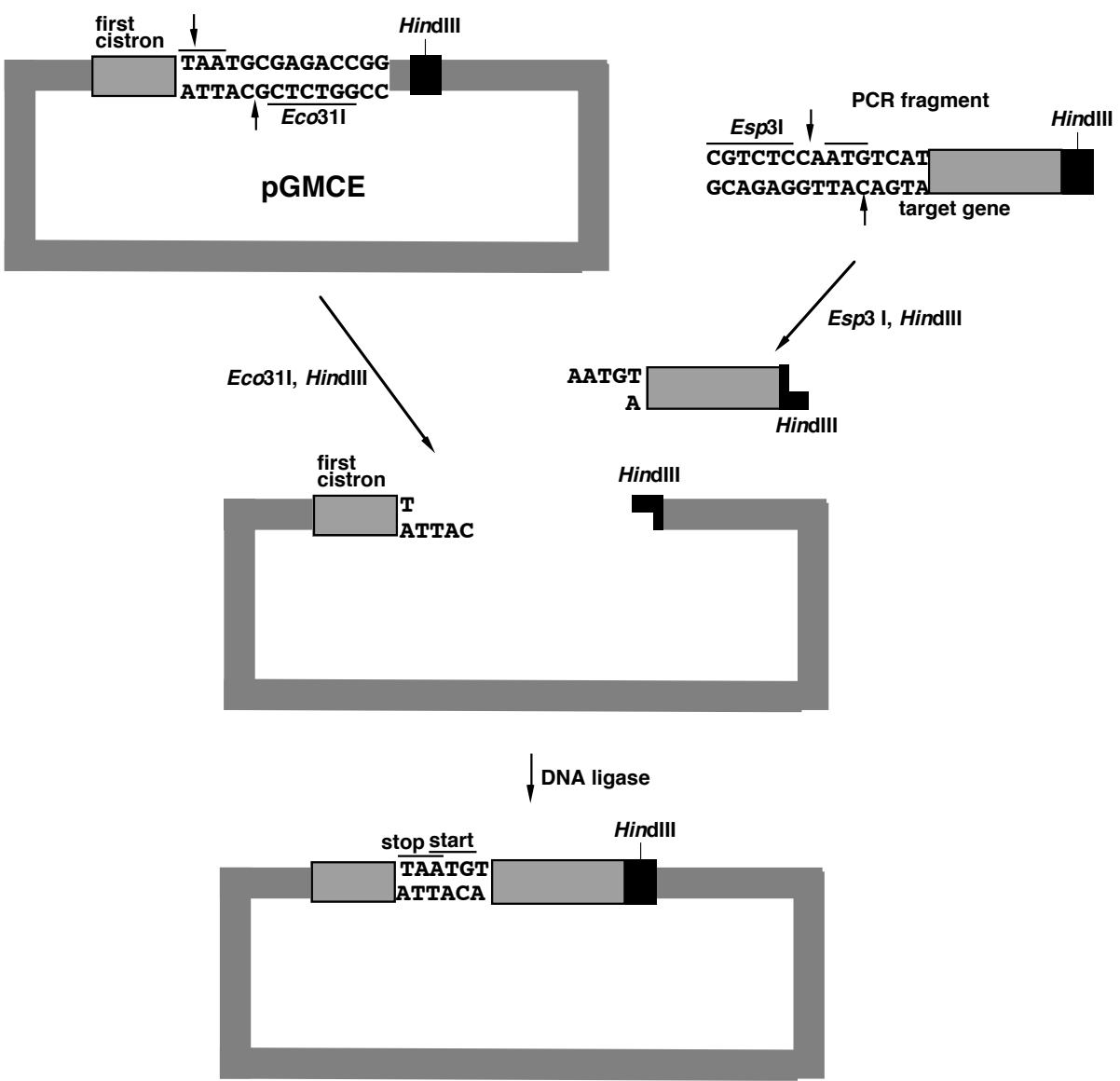

Figure 2. Schematic representation of the insertion of a gene encoding mature human IL1 $\alpha$ into the vector pGMCE (see text) by the SDL method to give a two-cistron expression system. The vector was used as a recipient after being digested with RE Eco31I and HindIII. The target gene, earlier synthesized by the same method as described, was excised from another plasmid by PCR. In this case, instead of Eco31I, a closely related, "isosteric" endonuclease Esp3I (CGTCTC, 1/5) was used, because the gene for IL1 $\alpha$ contains an internal Eco31I site. Thus, the upstream primer for excising the modified gene carried the Esp3I recognition and cleavage sites, and the downstream primer contributed a distal HindIII site and a termination codon. Positions of the cleavage sites are shown with arrows. 
recognition site, which makes it possible to insert the target gene downstream as a second cistron. For that goal, the target gene should be provided with a proximal REIIS recognition site and a cleavage site giving the corresponding cohesive end. This was achieved by means of a modifying PCR on the target gene as a template with a suitable upstream primer. The modified gene was inserted into pGMCE at the Eco31I/HindIII sites to give a two-cistron system with a high level of expression of the target gene.

It was shown that the function of this system depends on the nature of the gene cloned as a second cistron, which may affect the higher structure of the translation initiation region (TIR). Thus, the IL1 $\alpha$ gene in this system is translated directly from the distal TIR, using the minicistron segment as part of an efficient leader sequence. On the other hand, if the secondary structure hinders efficient translation from the distal TIR, the translation may initiate at the proximal TIR and proceed through the minicistron into the target gene transcript, as when the system is used for expression of the IL1 receptor antagonist gene (34). The same two-cistron system has also been used for cloning and high-level expression of a gene encoding the N15 bacteriophage telomerase (Lebedenko, Rybchin, and Berlin, unpublished).

It is important that in cloning various DNA fragments into the vector pGMCE, only one component of the SDL-joining should be amplified in vitro, while the other remains the same. This reduces the probability of PCR-induced mutations.

\section{Conclusions}

DNA splicing by directed ligation (SDL) is a method for recombining DNA fragments which takes advantage of the ability of class IIS restriction endonucleases to cleave outside of their recognion sites. The site itself can thus be removed, and does not appear in the final product. PCR makes it possible to introduce specially designed REIIS sites into the ends of any DNA fragment. The method's name derives from its utility in obtaining intronless eukaryotic genes by joining PCR-produced exons, but it can be employed for the in-phase joining of any PCR products. The approach is especially useful for creating a series of recombinants in which only one segment varies. Using endonucleases depreciates this approach to a certain extent as compared with the SOE method, which as far as enzymes go is content with DNA polymerase. On the other hand, SDL operates with exact (in terms of the length) PCR copies of DNA segments of the final joining products, which allows for the intermediate preparation and study of functionally significant DNA fragments (e.g., exons) and products of their expression. In addition, SDL involves fewer rounds of in vitro amplification, and the whole recombinant does not need to be amplified.

\section{Acknowledgments}

I am greatly indebted to E.N. Lebedenko and K.R. Birikh (Shemyakin Institute) for taking part in this study and (KRB) for preparing the figures, and for chemicalenzymatic assembly of a gene for interleukin 9 (Gulevich and Berlin, unpublished). My special thanks are due to R.M. Horton (Attotron Biosensor Corporation), who triggered the writing of this paper and generously edited the manuscript to set many an "out-of-joint" expresion. The work in the author's laboratory was supported by grants from the Russian State Program "Advances in Biotechnology" (direction "Genetic and Cell Engineering").

\section{References}

1. Khorana, H.G. 1979. Total synthesis of a gene. Science. 203: 614-625.

2. Lobban, P.E. and Kaiser, A.D. 1973. Enzymatic end-to-end joining of DNA molecules. J. Mol. Biol. 78: 453-471. 
3. Eschenfeldt, W.H., Puskas, R.S. and Berger, S.L. 1987. Homopolymeric tailing. Methods Enzymol. 152: 337-342.

4. Kessler, C. and Manta, V. 1990. Specificity of restriction endonucleases and DNA modification methyltransferases - a review (Edition 3). Gene. 92: 1-248.

5. Pingoud, A., Alves, J. and Geiger, R. 1993. Restriction Enzymes. In: Methods of Molecular Biology, Vol. 16: Enzymes of Molecular Biology. M.M. Burrell, ed. Humana Press, Totowa, NJ. pp. 107-200.

6. Saiki, R.K., Scharf, S., Faloona, F., Mullis, K.B., Horn, G.T., Erlich, H.A. and Arnheim, N. 1985. Enzymatic amplification of $\beta$-globin genomic sequences and restriction site analysis for diagnosis of sickle cell anemia. Science. 230: 1350-1354.

7. Saiki, R.K., Gelfand, D.H., Stoffel, S., Scharf, S.J, Higuchi, R., Horn, G.T., Mullis, K.B. and Erlich, H.A. 1988. Primer-directed enzymatic amplification of DNA with a thermostable DNA polymerase. Science. 239: 487-491.

8. Caruthers, M.H., Barone, A.D., Beaucage, S.L., Dodds, D.R., Fisher, E.F., McBride, L.J., Matteucci, M., Stabinsky, Z. and Tang, J.-Y. 1987. Chemical synthesis of deoxyoligonucleotides by the phosphoramidite method. Methods Enzymol. 154: 287-313.

9. Horton, R.M., Hunt, H.D., Ho, S.N., Pullen, J.K. and Pease, L.R. 1989. Engineering hybrid genes without the use of restriction enzymes: Gene splicing by overlap extension. Gene. 77: 61-68.

10. Horton, R.M., Cai, Z., Ho, S.N. and Pease, L.R. 1990. Gene splicing by overlap extension: Tailor made genes using the polymerase chain reaction. Biotechniques. 8: 528-535.

11. Horton, R.M. and Pease, L.R. 1991. Recombination and mutagenesis of DNA sequences using PCR. In: Directed Mutagenesis: A Practical Approach. M.J. McPherson, ed. IRL Press, Oxford. p. 217-247.

12. Kadowaki, H., Kadowaki, T., Wondisford, F.E. and Taylor, S.I. 1989. Use of polymerase chain reaction characterized by Taq DNA polymerase for sitespecific mutagenesis. Gene. 76: 161-166.

13. Lebedenko, E.N., Plutalov, O.V. and Berlin, Yu.A. 1990. Construction of eukaryotic genes by means of polymerase chain reaction: A gene encoding human interleukin-1 $\alpha$. Coll. Czech. Chem. Commun. 55, Special Issue 1: 269-272.

14. Lebedenko, E.N., Birikh, K.R., Plutalov, O.V. and Berlin, Yu.A. 1991. Method of artificial DNA splicing by directed ligation (SDL). Nucleic Acids Res. 19: 6757-6761.

15. Jayaraman, K., Fingar, S.A., Shah, J. and Fyles, J. 1991. Polymerase chain reaction-mediated gene synthesis: Synthesis of a gene coding for isozyme c of horseradish peroxidase. Proc. Natl. Acad. Sci. USA. 88: 4084-4088.

16. Szybalski, W., Kim, S.C., Hasan, N. and Podhajska, A.J. 1991. Class-IIS restriction enzymes - a review. Gene. 100: 13-26.

17. Cohen, S.N. 1981. Method for synthesizing DNA sequentially. US Patent 4293 652.

18. Korobko, V.G., Dobrynin, V.N., Severtsova, I.V., Boldyreva, E.F., Bystrov, N.S. and Kolosov, M.N. 1982. Oligonucleotide adaptors cleavable by restriction nuclease $\mathrm{HgaI}$ and their application for DNA synthesis. Bioorgan. Khim. 8: 830-839.

19. Korobko, V.G., Dobrynin, V.N., Severtsova, I.V., Boldyreva, E.F., Shingarova, L.N., Chuvpilo, S.A., Filippova, L.Yu., Zvonok, N.M., Vasil'eva, T.E. and Kolosov, M.N. 1987. A new approach to construction of DNA from synthetic oligonucleotides. Synthesis of DNAs coding for repeats of the antigenic determinant of mouth-and-foot disease virus. Bioorgan. Khim. 13: 69-81.

20. Dobrynin, V.N., Korobko, V.G., Shingarova, L.N., Bystrov, N.S., Filippov, S.A., Boldyreva, E.F., Kolosov, M.N., Matvienko, N.I. and Kramarov, V.M. 1984. Plasmid vector $\mathrm{pBBV}$ for cloning and regeneration of DNA fragments with 
arbitrary terminal sequence. Dokl. Akad. Nauk SSSR 278: 1002-1005.

21. Kravchenko, V.V., Serpinski, O.I., Sivolobova, G.F. and Shubina, T.N. 1987. Plasmid pNIMB - a universal vector for cloning, sequencing and directed assembly of genes. Mol. Biol. (Moscow) 21: 194-199.

22. Mandecki, W. and Bolling, T. 1988. FokI method of gene synthesis. Gene. 68: 101-107.

23. Sinyakov, A.N., Serpinskii, O.I., Danilyuk, N.K., Chizhikov, V.E. and Degtyarev, C.Kh. 1989. pMB123 and pMB124 vectors for producing DNA fragments with unique protruding ends. Bioorg. Khim. 15: 638-647.

24. Scharf, S.J, Horn, G.T. and Erlich, H.A. 1986. Direct cloning and sequence analysis of enzymatically amplified genomic sequences. Science. 233: 1076-1078.

25. Barnes, W.M. 1992. The fidelity of Taq polymerase catalyzing PCR is improved by an N-terminal deletion. Gene. 112: 29-35.

26. Bennett, B.L. and Molenaar, A.J. 1994. Cloning of PCR products can be inhibited by Taq polymerase carryover. Biotechniques. 16: 32, 37.

27. Crowe, J.S., Cooper, H.J., Smith, M.A., Sims. M.J., Parker, D. and Gewert, D. 1991. Improved cloning efficiency of polymerase chain reaction (PCR) products after proteinase K digestion. Nucleic Acids Res. 19: 184.

28. Berlin, Yu.A., Zvonok, N.M. and Chuvpilo, S.A. 1980. Synthesis of oligo and polyucleotides. XXXII. The synthesis of some linker and adaptor oligonucleotides and their interaction with the restriction endonucleases. Bioorg. Khim. 6: 1522-1535.

29. Berlin, Yu.A. and Butkus, V.V. 1981. Synthesis of oligonucleotides containing the GGTACC sequence and their interaction with the KpnI restriction endonuclease. Bioorg. Khim. 7: 1224-1232.

30. Anonymous 1996. Cleavage close to the end of DNA fragments. New England Biolabs 96/97 Catalog, p. 238-239.

31. Dinarello, C.A. 1994. Interleukin-1. Adv. Pharmacol. 25: 21-51.

32. Furutani, Y., Notake, M., Fukui, T., Ohue, M., Nomura, H., Yamada, M. and Nakamura, S. 1986. Complete nucleotide sequence of the gene for human interleukin 1 alpha. Nucleic Acids Res. 14: 3167-3179.

33. Birikh K.R., Lebedenko E.N. and Berlin Yu.A. 1994. Synthesis of a translation enhancer-containing vector for gene expression in a prokaryotic two-cistron system. Nucleosides Nucleotides. 13: 599-605.

34. Birikh, K.R., Lebedenko, E.N., Boni, I.V. and Berlin, Yu.A. 1995. A high-level prokaryotic expression system: Synthesis of human interleukin-1 $\alpha$ and its receptor antagonist. Gene. 164: 341-345. 


\section{Further Reading}

Caister Academic Press is a leading academic publisher of advanced texts in microbiology, molecular biology and medical research. Full details of all our publications at caister.com

- MALDI-TOF Mass Spectrometry in Microbiology Edited by: M Kostrzewa, S Schubert (2016) www.caister.com/malditof

- Aspergillus and Penicillium in the Post-genomic Era Edited by: RP Vries, IB Gelber, MR Andersen (2016) www.caister.com/aspergillus2

- The Bacteriocins: Current Knowledge and Future Prospects Edited by: RL Dorit, SM Roy, MA Riley (2016)

www.caister.com/bacteriocins

- Omics in Plant Disease Resistance Edited by: V Bhadauria (2016) www.caister.com/opd

- Acidophiles: Life in Extremely Acidic Environments Edited by: R Quatrini, DB Johnson (2016) www.caister.com/acidophiles

- Climate Change and Microbial Ecology: Current Research and Future Trend

Edited by: J Marxsen (2016)

www.caister.com/climate

- Biofilms in Bioremediation: Current Research and Emerging Technologies

Edited by: G Lear (2016)

www.caister.com/biorem

- Microalgae: Current Research and Applications Edited by: MN Tsaloglou (2016) www.caister.com/microalgae

- Gas Plasma Sterilization in Microbiology: Theory, Applications, Pitfalls and New Perspectives Edited by: H Shintani, A Sakudo (2016) www.caister.com/gasplasma

- Virus Evolution: Current Research and Future Directions Edited by: SC Weaver, M Denison, M Roossinck, et al. (2016) www.caister.com/virusevol

- Arboviruses: Molecular Biology, Evolution and Control Edited by: N Vasilakis, DJ Gubler (2016) www.caister.com/arbo

- Shigella: Molecular and Cellular Biology Edited by: WD Picking, WL Picking (2016) www.caister.com/shigella

-Aquatic Biofilms: Ecology, Water Quality and Wastewater Treatment

Edited by: AM Romaní, H Guasch, MD Balaguer (2016)

www.caister.com/aquaticbiofilms

- Alphaviruses: Current Biology

Edited by: S Mahalingam, L Herrero, B Herring (2016)

www.caister.com/alpha

- Thermophilic Microorganisms

Edited by: F Li (2015)

www.caister.com/thermophile
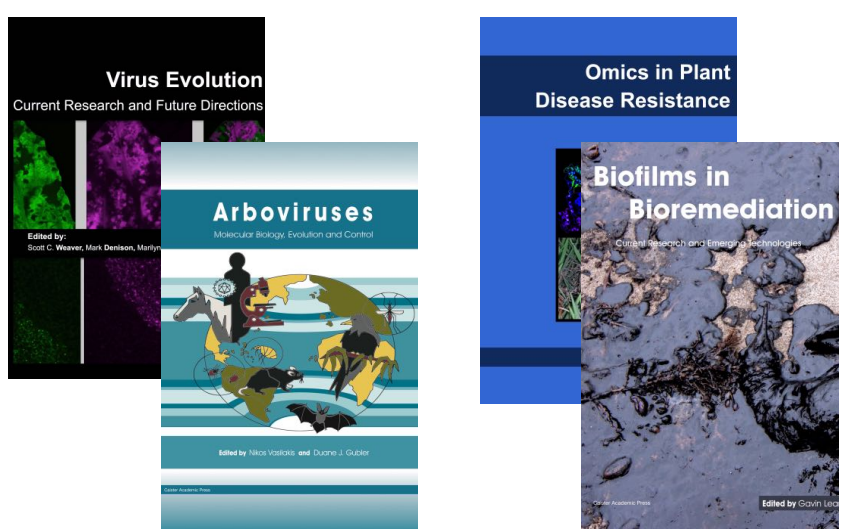
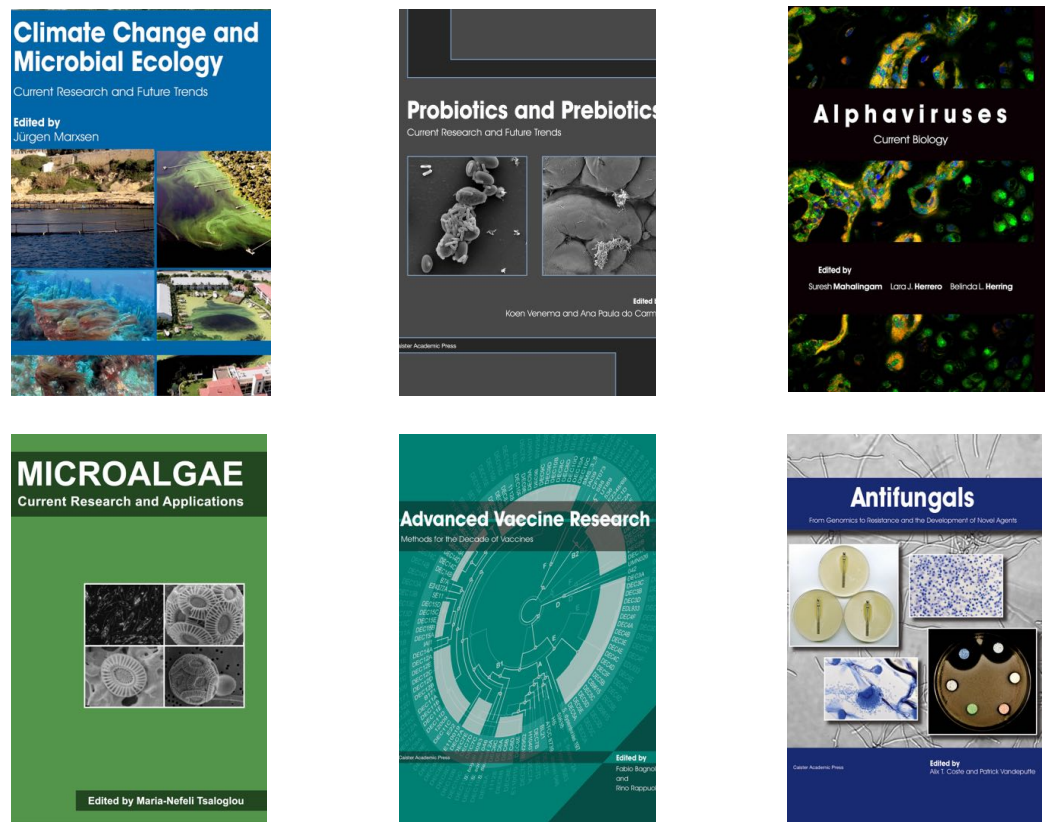

- Flow Cytometry in Microbiology: Technology and Applications Edited by: MG Wilkinson (2015) www.caister.com/flow

- Probiotics and Prebiotics: Current Research and Future Trends Edited by: K Venema, AP Carmo (2015) www.caister.com/probiotics

- Epigenetics: Current Research and Emerging Trends Edited by: BP Chadwick (2015) www.caister.com/epigenetics2015

- Corynebacterium glutamicum: From Systems Biology to Biotechnological Applications

Edited by: A Burkovski (2015)

www.caister.com/cory2

- Advanced Vaccine Research Methods for the Decade of Vaccines

Edited by: F Bagnoli, R Rappuoli (2015)

www.caister.com/vaccines

- Antifungals: From Genomics to Resistance and the Development of Novel Agents

Edited by: AT Coste, P Vandeputte (2015)

www.caister.com/antifungals

- Bacteria-Plant Interactions: Advanced Research and Future Trends Edited by: J Murillo, BA Vinatzer, RW Jackson, et al. (2015) www.caister.com/bacteria-plant

\section{- Aeromonas}

Edited by: J Graf (2015)

www.caister.com/aeromonas

- Antibiotics: Current Innovations and Future Trends

Edited by: S Sánchez, AL Demain (2015)

www.caister.com/antibiotics

- Leishmania: Current Biology and Contro Edited by: S Adak, R Datta (2015) www.caister.com/leish2

- Acanthamoeba: Biology and Pathogenesis (2nd edition) Author: NA Khan (2015)

www.caister.com/acanthamoeba2

- Microarrays: Current Technology, Innovations and Applications Edited by: Z He (2014)

www.caister.com/microarrays2

- Metagenomics of the Microbial Nitrogen Cycle: Theory, Methods and Applications

Edited by: D Marco (2014)

www.caister.com/n2 